Article

\title{
An Unseen Eighth Rune: Runic Legacy and Multiliteral Performativity in Cynewulf's The Fates of the Apostles
}

\author{
Jacob Wayne Runner
}

\section{check for}

updates

Citation: Runner, Jacob Wayne. 2021. An Unseen Eighth Rune: Runic Legacy and Multiliteral Performativity in Cynewulf's The Fates of the Apostles. Humanities 10: 124. https://doi.org/10.3390/ h10040124

Received: 4 November 2021 Accepted: 26 November 2021 Published: 3 December 2021

Publisher's Note: MDPI stays neutral with regard to jurisdictional claims in published maps and institutional affiliations.

Copyright: (C) 2021 by the author. Licensee MDPI, Basel, Switzerland. This article is an open access article distributed under the terms and conditions of the Creative Commons Attribution (CC BY) license (https:/ / creativecommons.org/licenses/by/ $4.0 /)$.
Faculty of Foreign Language Studies, Institute of Liberal Arts and Science, Kanazawa University, Kanazawa 920-1192, Japan; jwrunner@staff.kanazawa-u.ac.jp

\begin{abstract}
The four Old English poems containing the runic Cyn(e)wulf 'signature' have continuously provoked debate as to the characters' intratextual function and proper interpretation. While the prevailing view is that they are predominantly logogrammatic instantiations of traditional runic names, a case has nevertheless also been made for alternative words indicated by initialisms. Referencing both of these lines of reasoning in conjunction with a semiotic literary methodological stance, this article evaluates a single Cynewulf poem (The Fates of the Apostles) and its particular inclusion of runes amongst the bookhand alphabet characters. The assessment demonstrates the poem's multiliteral destabilization of associative boundaries between different scripts, as well as between perceived boundaries of orality and legibility. In doing so, it identifies in the text an unseen 'eighth rune' that is semiotically operative.
\end{abstract}

Keywords: old English poetry; runology; Vercelli Book; Cynewulf; semiotics; Multiliteralism

\section{Introduction}

Four instances of the runic name "KAT(M)PחN" (Cyn(e)wulf)" survive within different Old English religious poems divided between the Exeter and Vercelli Books (Exeter, Cathedral Library 3501; Vercelli, Biblioteca Capitolare CXVII). This rare inclusion of a personal name allowing for 'authorial' attributions has captivated generations of scholars, despite an elusive identity and the broader inapplicability of modern conceptions of authorship. The polygraphic manner of insertion amidst the surrounding lines of Latin alphabet bookhand, moreover, has prompted wide-ranging debates as to the characters' intratextual function and their proper interpretation. While the specific forms of implementation differ between Christ II, Juliana, The Fates of the Apostles, and Elene, the prevailing conventional view is that the runic insertions function logogrammatically, instantiating traditional runic names (e.g., Birkett 2014a, 2017a, pp. 70-75; 2017b; Elliott 1953a, 1953b, 1991; Page 1999; Symons 2016, pp. 85-120). A case has, however, been made that the runes may represent alternative words indicated by initial letter (Niles 2006, pp. 285-306). By drawing upon both of these divergent lines of reasoning and approaching the text from a semiotic literary perspective, this article will offer a reassessment of The Fates of the Apostles and its runic 'signature' passage. First, I shall demonstrate how the poem multiliterally subverts the associative boundaries between the distinct scripts in use and also between orality and legibility. Second, I will construct an argument that rather than primarily marking a separation, the destabilization of expectations and boundaries achieves an integrative effect. As a concluding result, I shall identify the relevance and semiotic operation of an unseen and hitherto unremarked 'eighth rune' in the passage.

At just 122 lines, The Fates of the Apostles of the later tenth-century Vercelli Book (fols. $52^{\mathrm{v}}-54^{\mathrm{r}}$ ) is the shortest of the surviving Cynewulf poems by a considerable margin. Not unlike the Exeter Book's hagiographical Juliana, certain early commentators were less than forgiving of the work's literary merit and deemed it to have "attracted more attention than many critics thought it deserved" in the wake of its recognition as a work associated with Cynewulf (Bjork 2013, p. xvi). ${ }^{1}$ This underappreciation for The Fates of the Apostles stems 
largely from its textual format, since in terms of structure the poem has much in common with Latinate passionary lists. It describes in concise fashion the evangelical achievements of Christ's twelve apostles in the early days of the Church and relates the manner of their deaths. For example, the poem gives a concise summary of Peter and Paul's martyrdom on four lines:

"Sume on Rome-byrig,

frame, fyrd-hwate, feorh ofgefon

purg Nerones nearwe searwe

Petrus ond Paulus."

"Notable men in Rome,

bold, warlike, gave up their lives

through Nero's cunning treachery,

Peter and Paul." (Bjork 2013, pp. 130-31, 11. 11b-14a; subsequent citations of the poem and Modern English translations are also drawn from Bjork's edition, unless otherwise noted)

It then transitions briskly to an account of the disciple Andrew.

In terms of direct source material, similarities and parallels have been noted between The Fates of the Apostles and continental martyrologies including the works of Florus of Lyon, Usuard of Saint-Germain-des-Prés, and Ado of Vienne, but according to an investigative reassessment pursued by John McCulloh, there is no positive, single source that can at present be identified (McCulloh 2000; see also Allen and Calderand 1976, pp. 35-39). Cynewulf may have collated information from multiple discrete sources or, as McCulloh alternatively theorizes, taken inspiration from a now lost passionary collection made up of writings by different individuals (McCulloh 2000, pp. 82-83). Either supposition aligns with the indications given by the poem in its opening lines:

"Hwæt. Ic pysne sang sið-geomor fand

on seocum sefan, samnode wide"

"Listen. Journey-weary, I devised this song

in my sick heart, gathered widely" (Bjork 2013, pp. 130-31, 11. 1-2; emphasis mine)

The Fates of the Apostles itself has not always even been viewed as independent from the work which directly precedes it in the Vercelli Book, Andreas. Occasionally in the past, both were taken together as a single larger work ascribed to Cynewulf, but more recent analyses of meter and diction highlight discrepancies between the two and link The Fates of the Apostles with the other signed poems (Fulk 2001; Orchard 2003). That said, Andreas does share commonalities with the 'Cynewulf canon,' including twice as many corresponding poetic formulae as the work with the next highest frequency (Guthlac B-also theorized possibly to be an unsigned Cynewulf poem), suggestive of "either unity of authorship or conscious literary borrowing in one direction or other" (Orchard 2003, p. 287). ${ }^{2}$ The orthodox contention is that the Andreas poet was more likely the borrower (Krapp 1906; Orchard 2003; Schaar 1967), but the opposite direction of influence has nevertheless also been proposed. Puskar (2011) emphasizes discordant notions of authorship and argues that the manuscript evidence points toward the scribe of the Vercelli Book perceiving Andreas and The Fates of the Apostles as a single work. Puskar further speculates that Cynewulf might not have functioned as the original poet in a modern sense, but could very well have compiled, rearranged, combined, and added to texts already in existence as part of the creative process. While it is not my intention here to provide a comprehensive resolution to the debate, these conflicting hypotheses bear mentioning if for no other reason than the fact that such paratextual elements inarguably hold sway over perceptions of the poem as a whole, over perceptions of its polygraphic epilogue, and especially over perceptions of 'Cynewulf' as an internal poet figure. ${ }^{3}$ 


\section{Naming Names}

From the top of folio $54^{\mathrm{r}}$ of the Vercelli Book, the poet figure reveals himself by gesturing within the text's discourse and by lacing individual runes into the lines of Latin alphabet character text beginning from line 98 . The relevant portion of the manuscript is now marred, but still generally decipherable, and edited as follows:

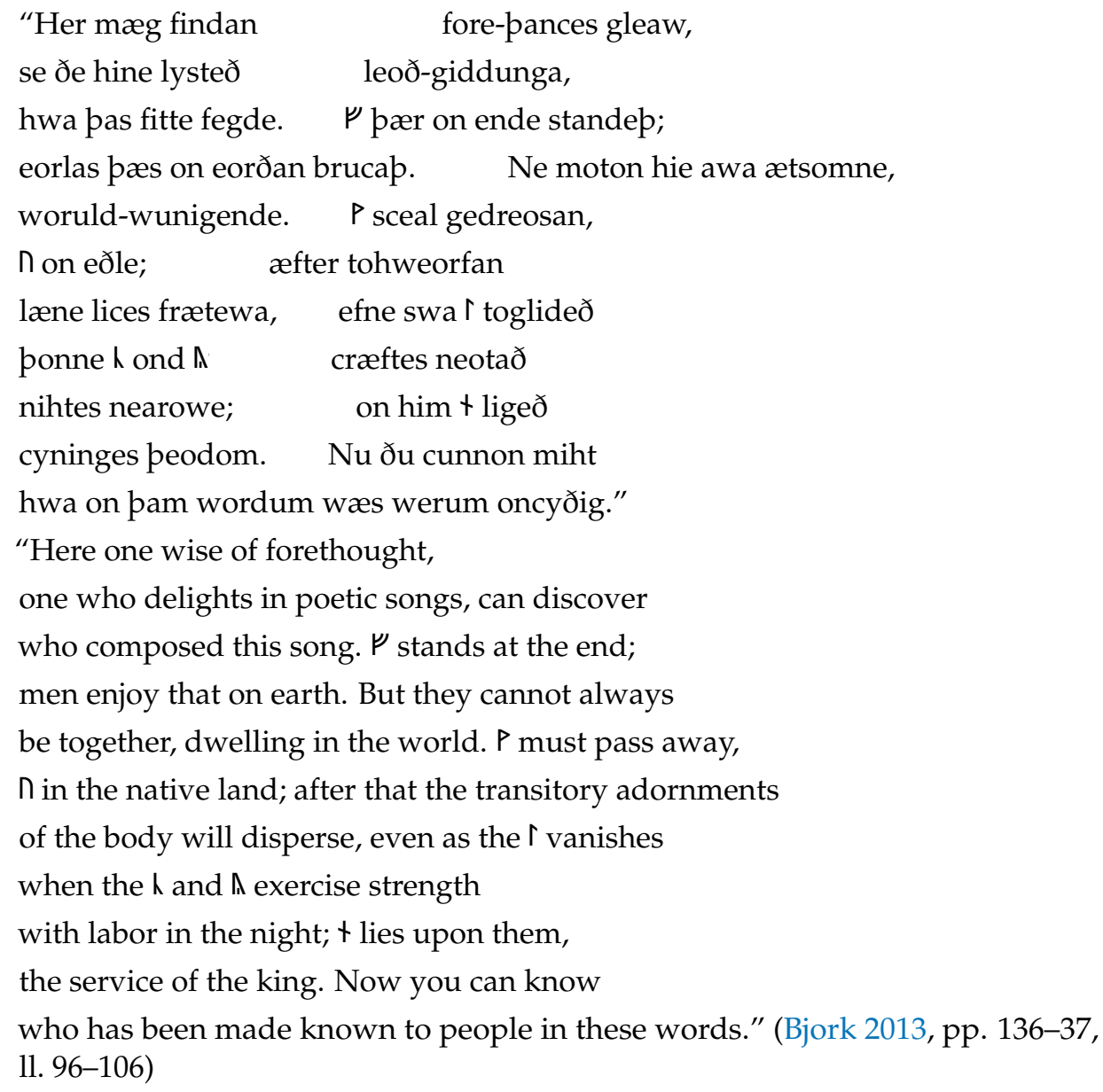

As with other instances of the signed Cynewulf canon, this polygraphic implementation of manuscript runes operates at several interrelated semiotic levels and demands a certain level of proficiency with both scripts. ${ }^{4}$

First, there is a fundamental differentiation between scripts that is immediately perceptible to the eye. The verse unambiguously indicates that here may be found "hwa pas fitte fegde". Attention is drawn to the presence of a poet persona, and the isolated individual runic letters can be arranged to provide the proper name 'Cynwulf.' Moreover, the runes' size and angularity visibly set them apart from the remainder of the surrounding Latin alphabet characters, meaning that even the wynn rune $(P)$ of the signature would appear distinct from the more rounded wynn $(P)$ employed throughout as a normal, 'unmarked' character of the book hand alphabet. This visual juxtaposition and differentiation between two operative sets of linguistic symbols imbues script choice itself with semiotic function. That is to say, in addition to functioning as a linguistic medium conveying the words of the poem, the recognition that one script has been used in place of another produces supplementary emblematic values that are bound up with the linguistic content.

These emblematic values can be associative or emotive in nature, as indeed Tom Birkett reminds us, "scripts represent cultural signifiers as well as practical technologies" (Birkett 2017a, p. 13). Moreover, auxiliary multiliteral signification is made possible because the runes are not mere visual adornments. Each rune denotes a word that contributes to the narrative, alliteration, and scansion of the line in which it appears. General scholarly 
consensus is that the runes should be interpretated as logograms that indicate traditional runic names. Thus, for example, the following initial rendering can be produced:

hwa pas fitte fegde. $\quad \psi \quad((\mathrm{f})=\mathrm{FEOH})$ pær on ende standep

who composed this song. (WEALTH, PROPERTY, etc.) stands at the end

Such a neatly coherent treatment is not possible in every case, however.

On one hand, the readings of $\Psi(f)=$ feoh (wealth, property, cattle); $P(w)=$ wynn (joy, delight); $\uparrow(1)=$ lagu (water, sea); and $+(\mathrm{n})=$ nyd (need, affliction) are comparatively less problematic, in that they indicate more commonplace Old English words that accord with the sense of the passage. $\mathrm{K}(\mathrm{c}), \mathbb{A}(\mathrm{y})$, and particularly $\mathrm{n}(\mathrm{u})$, on the other hand, are altogether thornier to unpack.

In terms of name values, one does not begin from a place of great assurance. For h (c), the name suggested by the Old English Rune Poem is "cen (torch)," a word that is exceedingly rare in Old English - to the point that it is even difficult to be certain whether it is Germanic in origin-and which is also not cognate with the name given by the later Icelandic and Norwegian rune poems ("kaun (sore, ulcer)") (Page 1999, p. 69). ^ (y) is doubly troublesome. It is a newer letterform encountered in the expanded English fuporc, and the name proposed for it, " $y r$," has an elusive description that prompts a number of possible meanings for the word. These include "saddle," "horn," and "bow" — the last of which options Ray Page calls the "most tempting" for the links it may confirm to the Scandinavian rune glossed "ýr (yew, bow, bent bow, etc.)" (Page 1999, p. 76). Alternatively, Michael Barnes suggests that the shape of the $\AA$ (y) rune seems to reflect the creators' realization of the sound's relationship to $\mathrm{n}(\mathrm{u})$ and $1(\mathrm{i})$, and that the name given to the character (" $y r$ ") is "most readily explained as an adaption of $u r$ [ . . ] yr is of uncertain meaning in Old English, if indeed it has any meaning at all" (Barnes 2012, p. 39).

The reading and translation of:

ponne $\mathrm{K}((\mathrm{c})=\mathrm{CEN})$ ond $\mathbb{A}((\mathrm{y})=\mathrm{YR}) \quad$ cræftes neotað nihtes nearowe

when (TORCH) and (SADDLE/HORN/BOW) exercise strength with labor in the night

in The Fates of the Apostles is perhaps a bit less jarring than in other Cynewulf poems, ${ }^{5}$ though it is still somewhat dissonant. In response, certain early commentators were especially driven to search for replacement c- and y- words, and John Niles more recently picks up such treatments and puts forward a renewed case for Cynewulf's use of initialisms rather than "slavish fidelity to the textbook names of the runes" (Niles 2003; 2006, p. 301). For The Fates of the Apostles' problematic K (c) and $\mathbb{A}(\mathrm{y})$ runes specifically, Niles proposes "the two antonyms cén $p u$ 'boldness' and irgp or irgpu 'cowardice'" as potential options that align thematically with the passage and Cynewulf's overall pattern of transposing the language of heroic verse to religious narratives (Niles 2006, p. 303). More than "one specific application," however, Niles's pivotal contention is rather for "a mode of interpretation" and "the principle that there exists no list of 'correct' rune-names that one can consult to decode Cynewulf's signatures" (Niles, p. 304, Niles's emphasis). This critical suggestion is one that I believe to be undervalued, especially as Niles explicitly does not suggest that it is never the conventional name.

Indeed, Kenneth Sisam's foundational assertion remains true and highly relevant; the attested runic names must serve as the starting point and standard against which any critical interpretation of the Cynewulf runes is judged (Sisam 1953, pp. 18-20). ${ }^{6}$ Yet across the board, exceedingly few modern commentators are willing to uphold the hardline stance of Ralph Elliott, who argues:

"In the first place, there must be some evidence justifying the substitution of any other word for the rune-name and its accepted meaning; the mere fact that some other word beginning with the same letter makes acceptable sense does not appear to constitute a sufficient criterion. In the second place, there must be consistency" (Elliott 1953a, p. 50) 
Consistency seems an entirely defensible principle, but Elliott's conservative approach produces an altogether less than convincing explanation for the $\mathrm{n}(\mathrm{u})$ rune, since construal with its name from the rune poem-“aurochs, ox, bison, etc." — produces an undeniably cryptic reading. ${ }^{7}$ Elliott's own resolution draws on the possibility that, "with [the older meaning of aurochs] there also remains the earlier symbolic significance of "male strength" (Elliott 1953a, p. 52). The concept of masculine strength would afford a reasonable interpretation of the line, but Elliott's rationalization for metaphorical extension has met with a large degree of justified skepticism (see (Elliott 1991) for a renewed defense of his views against the challenges made by Page and others).

The more common, if in some ways less defensibly consistent, interpretation of the rune is that it represents the homonymous pronoun correlating to Modern English "our," i.e., "ure on eðle," rendered by Birkett as "'u' (our) 'w' (joy) [from the previous line] in the native land" (Birkett 2014a, p. 780). This reading is attractive, because of the comprehensible senses it produces not only here in The Fates of the Apostles, but also in Christ II and Elene. Yet, while the sense offered is certainly acceptable, it is intensely problematic strictly in terms of audible detectability. Even if one is made appropriately aware of the presence of runic names in the passage, otherwise unguided listeners face a taxing multilayered challenge. They must link a common pronoun with a homonym that is associated with a rune, all while maintaining an overall awareness of the poem's narrative, a mental list of common and uncommon rune names already successfully extracted from the recited text, and an alert ear listening closely for runes still to come. Beyond the high degree of literacy and textual awareness this necessitates, the implications of such a substitution render a daunting auditory task a nearly impossible one.

If, indeed, "ure (our)" is the correct interpretation, then surely deviation from conventional names would further hinder one's capacity to detect the runes in a purely aural setting. Even if a listener could make the necessary leaps to arrive at its being a runic letter in the name Cynwulf, this homonymous substitution disrupts the stability of a listener's interpretative framework in much the same way an entirely arbitrary substitution would. The audience must suddenly question whether similar substitutive processes will continue to take place or have already been taking place without their recognition. Doubt is cast on the previous rune words which a listener had theoretically been able to extract successfully. This demonstrates the difficulty - if not impossibility — of untangling the signature from the polygraphic epilogue without some form of non-verbal indication or visual confirmation. It also reveals that the aesthetic result of the signatures is far more than simply a request for remembrance and prayers.

\section{The Poet's Involvement}

Had preservation of Cynewulf's name been the sole purpose, then an alternative method could have easily been taken to convey his name efficiently to both reader and listener, such as perhaps the use of an acrostic, unbroken alliteration, or a simple colophon; even if Cynewulf refrained from such direct means, Victoria Symons additionally points out that if the goal truly had been only to elicit prayers, then at least electing to employ a uniform epilogue would seem better suited to that purpose (Symons 2016, p. 90). Instead, Symons presents the convincing case that,

"Rather the Cynewulf poet uses these embedded runes in order to explore the material nature of the written word and its ability to function as a visual symbol, and to remind readers of the necessity of correctly interpreting what is read. These epilogues are designed primarily for the benefit of the reader's reflection rather than the poet's posterity." (Symons 2016, p. 85)

This reflective aspect is an essential component for understanding the Cynewulf poems' intratextual use of runes, but it is beneficial to extend the consideration. Elsewhere, Symons contends that "Readers of these passages are relied upon to bring to the verse a shared understanding of conventional rune names which is then subverted, through substitutions and metaphors, in ways that test the flexibility of runic letters as written 
signifiers" (Symons 2016, p. 98). This too is persuasive, and yet a reduction of the runes to little more than embellishing visual symbols with linguistic associations is unhelpfully limiting, and I would argue that it is likely overly informed by modern monoscriptal writing perspectives (on the broader subject of historical and contemporary linguistic contexts that exceptionally and routinely use multiple scripts, see first (Bunčić et al. 2016)).

The signature runes possess a different status and function than the Latin alphabet letters of the text, but this is not in and of itself atypical for polygraphic writing more generally. Nor, I would highlight, is it even particularly idiosyncratic with respect to the Old English context, where the paleographical record displays a deliberate and patterned hierarchy of letterforms "of various degrees of formality, allowing scribes to adapt their handwriting to suit the status of their texts or the space available" (McKee 2014, pp. 423-24; see also Brown 2011). ${ }^{8}$ The runic signature epilogues should thus be approached and viewed as elements that contribute to the overarching aesthetic aims of their respective texts. While the insertion of runes does create a visual disruption, in none of the Cynewulf poems is it a sudden break with what has come before. For clarification, the most revealing place to turn is to the poem itself.

The signature passage is not simply a personal, first-person epilogue that has been clumsily appended to a poetic listing of the apostles. Exploration of the poem's themes and overall format sheds light on what is revealed by the runes and on their multiliteral implementation. Daniel Calder succinctly summarizes how,

"Cynewulf's own personal cares (conventional as they may be for a medieval Christian) define the themes of the poem - both in the narrative and the runic conclusion [ ... ] In the iterated prayers one item in particular, noted above, is repeated - the journey to an unknown land (91b-95b, 108b-113a). Faced with genuine terror about this journey, Cynewulf finds its parallel and consolation in the journeys of the twelve apostles." (Calder 1975, p. 222)

Even more conspicuously than in the other signed works, Cynewulf's personal involvement in The Fates of the Apostles is no hastily appended afterthought. It is woven into the fabric of the poem in such a way that the inclination to spell out his name after those of the apostles seems altogether intuitive, as Elliott (1991, pp. 232-34) and numerous previous commentators have recognized. James Boren highlights particularly how Cynewulf's first-person segment "functions in the same relationship formally and thematically as do the personae of the apostles"; the poet not only effects structural and thematic unity through the repetition of rhetorical patterns over the course of the poem but also successfully "identifies himself with the apostles" (Boren [1969] 2001, p. 61). ${ }^{9}$ Constance Hieatt further observes a thirteenth corresponding occurrence which somewhat spoils the apostolic symbolism of Boren's twelve, but which nevertheless reinforces the general validity of the pattern (Hieatt [1974] 2001, p. 71).

Though we can discern little about Cynewulf's biography and historicity, it is hard to overstate his importance in figural terms, since he serves a central, intratextual function as a poet persona. I would also suggest that, in this role as a rhetorical device, the poet figure helps first and foremost to facilitate reader reflection and to allow for easier identification with the righteous characters contained in the main narrative. The poet strives to affiliate himself with the figures of the apostles and then unmistakably extends this same affiliation to the discerning reader on lines 96-98a, 107-9. He achieves this through: (1) explicit hints aimed at "one wise of forethought, one who delights in poetic songs"; (2) secondperson address; and (3) direct first-person entreaty. This ties in with the poem's structure of interconnected images and metaphors which, as Hieatt writes, "suggests progression which goes something like 'Christ $>$ saints > poet > reader > humanity > God?'" (Hieatt [1974] 2001, p. 76). It chimes too with Dolores Frese's assertion that, "By employing a similar verbal pattern for apostolic and poetic activity, Cynewulf relates the reader, the poet, and the entire Christian brotherhood in a kind of poetic communion of saints" (Frese 1975, p. 320). 
I would likewise contend that the polygraphic inclusion of runes further accentuates this ideological affiliation by associatively reemphasizing the significance and applicability of the poem's message for a reader of the vernacular in Early Medieval England. The runes' emphasized distinctiveness and their lingering relevance as cultural symbols in the period tantalizingly suggest ties to layered notions of linguistic and sociocultural heritage, origins, and identity management. These complex and charged topics are ones which modern commentators would do well to engage with carefully and self-reflectively, not only because of the high potential for incendiary and racist misappropriation, ${ }^{10}$ but also because of the equally high potential for scholarly reductivism.

In Robert DiNapoli's estimation, for example,

By using runic characters, Cynewulf also affirms the esoteric lore of his native Germanic heritage even as he bids it farewell. He uses the cultural associations of the runic alphabet here to locate himself with a poignant exactitude on the mental watershed that divides the Anglo-Saxon poet's pagan past from his Christian present and future. (DiNapoli 2005, pp. 160-61; emphasis mine)

However, I wish to argue precisely the opposite. In actuality, Cynewulf defies onedimensional categorical expectations and blurs conventional boundary lines between cultures, traditions, and languages, as even the runic signatures appear to have a blended literary pedigree. Just as they can be related to 'native' Germanic maker inscriptions and riddling traditions, they have conversely been linked also to acrostic techniques from within the spheres of medieval Latin poetry (Birkett 2017a, pp. 70-75; Christie 2003, p. 132; Gleason 1992).

The Fates of the Apostles is unique even among the signed Cynewulf canon in that the runes are not encountered in proper name sequence as one reads through the poem. They appear in the order: F, W, U, L, C, Y, N. This shuffling combined with the indicative hints that precede and follow the runes led Elliott to assert that: "There is, however, more of the traditional riddle than in either Christ II or Elene" (Elliott 1953b, p. 195). The reader is indeed encouraged to decipher and puzzle out the intratextual anagram, but I am entirely wary of associative interpretations of the runes themselves as intrinsically cryptic or as “ambiguity incarnate" (DiNapoli 2005, p. 161). Instead, I would suggest that DiNapoli's view and similarly divisive preconceptions are more than likely informed by modern cultural perspectives on cryptic 'heathen' runes and misrepresentative of on-the-ground realities in the contexts of Early Medieval England.

Quite to the contrary, not only has it been surmised that the Church and monastic institutions could well have played a hand in a seemingly deliberate runic reform that took place earlier from around the late seventh century (Parsons 1999), Birkett has advanced a convincing theory that the use of and reference to runes in early English manuscripts actually appear to exhibit "unlocking" or "releasing" qualities of solution, which he suggests are best encapsulated by the Latin term "revelatio," with its twin meanings of both "uncovering" and "revelation" in the Modern English sense (Birkett 2014a; 2014b; 2017a, chp. 2, pp. 49-81). Proceeding from that standpoint, the runes in The Fates of the Apostles do not need to be interpreted as merely adding a simplistic layer of visual encryption or disguising certain letters and words. They can instead be perceived as contributing to the message of the passage and the poem in their own reflective and revelatory way.

In part then, my own ultimate assessment of the textual runes is in accord with those of Orton (2014) and of Gleason (1992). I generally agree with the associative and reflective notions that "the memory of [runes'] original epigraphical role would also have helped the reader to understand their purpose and significance" (Orton 2014, p. 132), and that as an "object of religious meditation" the runes may go beyond designating individual words and letters of the name perhaps to "evoke within the context of the poem a tradition of Christian runic lore to 'whisper' a moral allegory on the mysteries of salvation" (Gleason 1992, pp. 19,28). Indeed, my overall argumentative trajectory is in line with the points both raise in relation to visuality and Cynewulf's manipulation of runic associative ties that may have existed in the minds of his audience(s). Yet, that is 
not the whole story. I would double-back one final time in order to underscore that the opposite also holds true. An overemphasis on only the written nature of the text is no less misleading than a focus only on its orality.

\section{A Multiliteral Eighth Rune}

It is crucial to balance conceptually both the transcribed and the aural aspects at work in the poem's passage. For, if we approach anachronistically with a modern monoscriptal writing and/or silent reading viewpoint, it is all too easy to miss a striking example of multiliteral semiosis that occurs in the passage. Associative signification that crosses script boundaries appears not only in connection with the runes, but also derives from a word that is transcribed in Latin alphabet letters.

Seven runes which comprise the poet's name present themselves and are theoretically visible to a silent reader. If one reads the passage aloud, or listens to it for that matter, there is a dynamic allusion to an eighth rune that is aurally accessible, but not literally included. As seen in the manuscript (reproduced below in Figure 1 from (Turco 2016)), the half-line 101a presents one rune and two Latin alphabet words: " $\Pi$ on eðle ( $\mathrm{n}$ in the native land)".

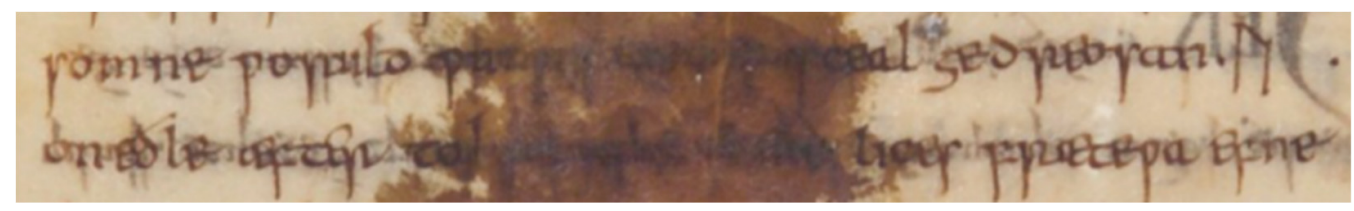

Figure 1. Detail from the signature passage in The Fates of the Apostles. " $n \cdot$ " concludes its line on the right, "on eðle" begins the next. Biblioteca Capitolare of Vercelli, (MS. CXVII, Codex Vercellensis, f. 54 ${ }^{\mathrm{r}}$ ) Copyright: Fondazione Museo del Tesoro del Duomo e Archivio Capitolare di Vercelli. Permission for reproduction granted by Silvia Faccin-Curator of manuscripts and rare books of Biblioteca Capitolare.

It is possible here to identify a graphically obscured reference to an additional runic name. "Eðle," translated by Bjork as "native land," is an inflected form of "eðel" or "cepel." This word also has the senses of "property," "inheritance," "land," "ancestral home," etc., and it is the traditional runic name suggested by the Old English Rune Poem for the $\otimes$ (œ) rune. ${ }^{11}$ Furthermore, $\widehat{\chi}(œ)$ is one rune that appears very occasionally in specific manuscript instances as an apparent stand-in for its traditional name, e.g., at line 520 of Beowulf. In light of the fact that a proper recitation of the signature section demands a degree of multiscriptal proficiency and presumably a familiarity with rune names, this allusion across scripts cannot have gone unnoticed. A reader can see the workings of one script through the other.

This observation has the practical repercussion of further compounding the difficulty of properly extricating the signature runes for an audience listening to the passage for the first time and provided with no supplementary cues. Indeed, Cynewulf's Christ II actually presents a corresponding difficulty. It employs Latin alphabet "lif-wynna (of lifejoys)" (1. 806) following directly on from " $\mathrm{P}(\mathrm{w})$ (wynn)" (1. 804); likewise, Latin alphabet "lagu-flode (sea-flood)" appears toward the close of Christ II (1. 850), recalling the apparent polygraphic compound "T(l) (lagu)-flodum" that is encountered on line 806. The particular half-line I have highlighted here from The Fates of the Apostles, however, is exponentially more complex to unpack in semiotic terms.

Whereas the difficulty in Christ II arises in relation to the comparatively commonplace Old English terms "wynn" and "lagu," The Fates of the Apostles' Latin alphabet "eøle" follows immediately on the heels of the " $\mathrm{n}(\mathrm{u})$ " rune which has prompted such great controversy of interpretation. It is still hypothetically possible that $\mathrm{n}(\mathrm{u})$ is meant to give "ur (aurochs)" in the sense of masculine strength as Elliott maintains (Elliott 1953b, 1991), but if we accept the more prevalent conjecture of "ure (our)," then in the space of three short words there is a convoluted inversion of graphic and associative expectations, one that is in all likelihood intensified by the hemistich's division across one line to the next in the original manuscript. 
A word that is not a traditional runic name (ure) must be re-understood as a rune for the visual purposes of spelling out the name, immediately prior to the appearance of an inflected form of a traditional runic name (eðle) transcribed in the Latin alphabet. This means that on top of the polygraphy and visible mixing that takes place on the page through reordering of the name's letters, there is an aural layer that underlies both scripts and which plays off of established associations to contribute to the reflective and interactive nature of the passage. Drawing upon these associations, multiliteral signification serves to apply auxiliary semiotic value to one's perceptions of the passage and its linguistic content.

Far from a binary that bids Germanic cultural conventions farewell or establishes an irreconcilable separation between 'the past' and those of Latinate Christianity, Cynewulf seeks not only structurally, thematically, and associatively, but as I have demonstrated, also multiliterally, to weave himself and his English-reading audience(s) into the ideological contexts of Judeo-Christian history and Western European Christendom. The reflection that the passage prompts is not inclined toward division, but rather toward both literal and conceptual integration.

Funding: This research was funded by the Japan Society for the Promotion of Science (JSPS), KAKENHI Grant-in-Aid for Research Activity Start-up-Project: "Transhistorical Approaches to Multilingualism and Multiliteralism in Early English"; Grant number: 21K20011.

Acknowledgments: Sincere thanks are owed to Maike Oergel and Christina Lee for their guidance and feedback during the development of this research. And Sawako, always.

Conflicts of Interest: The author declares no conflict of interest. The funders had no role in the design of the study; in the collection, analyses, or interpretation of data; in the writing of the manuscript, or in the decision to publish the results.

\section{Notes}

1 Modern transcription of the Vercelli Book took place from 1834, but recognition of The Fates of the Apostles' association with Cynewulf followed on from Napier (1889)'s publication: “Collation der altenglischen Gedichte im Vercellibuch." See further (Calder 1981, p. 29).

2 For reference, the formulae under scrutiny are those metrically modular phrases which may be "screened out [...] of the traditional and inherited formulae" (Orchard 2003, p. 273), and which appear shared across poems of the Cynewulf canon vs. the remainder of the surviving corpus of Old English verse.

3 By 'paratextual,' I refer to those facets of a text which under Gérard Genette's theoretical schematic serve to locate and identify it for a reader, such as Authorial or Prefatory information, formatting, etc. (Genette 1997).

$4 \quad N B$. While a more comprehensive discussion falls outside of the scope of this article, it bears mentioning that there is considerable debate surrounding runic literacy across periods and the historical connections (or lack thereof) between the divergent productive spheres of runic epigraphy and later period manuscript writing. My aim in this section is not to oversimplify paleographical studies, manuscript runology, nor the complex historical questions of origin, continuity, revival, and influence. See first: (Derolez 1954, 1990, 1991).

$5 \quad$ E.g., Compare to Christ II, 11. 800-01a: "pendan $\mathrm{h}((\mathrm{c})=\mathrm{CEN})$ ond $\mathbb{A}((\mathrm{y})=$ YR) ypast meahtan / frofre findan (while (TORCH) and (SADDLE/HORN/BOW) could most easily / find comfort)" (Bjork 2013, pp. 26-27).

6 In addition to the Old English Rune Poem, Sisam highlights the evidence of the description of the English runic alphabet and rune names in the ninth-century Codex Vindobonensis 795 (Salzburg 140), and the later evidence of three early twelfth-century lists in: Cotton Manuscripts Domitian A IX, Galba A II (now destroyed), and St. John's College Oxford Manuscript 17.

7 NB. There is also a discrepancy in the rune's name as related by the Old English, Norwegian, and Icedlandic rune poems. Senra Silva (2010) has proposed that this could be due to understandably growing ignorance of the aurochs, an animal which survived only in continental forests.

8 Sc. In order of descending formality, scripts employed include: Insular Half-Uncial, Hybrid Minuscule, Set Minuscule, Cursive Minuscule, Current Minuscule.

9 Specifically, Boren highlights the recurrence of three discernible elements in the individual narrative sequences which he terms: the "nominative element" (designating the subject of the action, frequently one of the apostles), the "locative element" (defining the setting or place of action), and the "instrumental element" (establishing the means by which an action is attained, i.e., often the figures of the apostles' persecutors through whom their martyrdom is effected).

10 To highlight but one case-in-point example in this vein, Damian Fleming has acknowledged and responded to problematic reappropriation and ideological projection by racist groups that is pertinent to a critique of his own previous scholarship: Damian 
Fleming. 2017. Ethel sweet Ethel-weard: The First Scribe of the Beowulf Manuscript. MedievalFleming: 14 November. Available online: https:/ / medievalfleming.wordpress.com/2017/11/14/ethel-sweet-ethel-weard-the-first-scribe-of-the-beowulfmanuscript/ (accessed on 1 October 2021). See Damian Fleming. 2004. Epel-weard: The First Scribe of the Beowulf Manuscript. Neuphilologische Mitteilungen 105: 177-86.

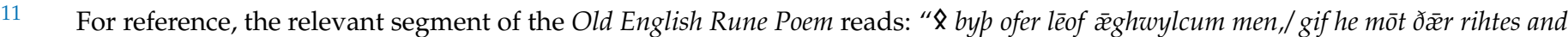
gerysena on/ brücan on bolde blēadum oftast (The family land is very dear to every man,/ provided that there in his own house he may enjoy/ everything that is right and proper in constant prosperity)" (Halsall 1981, pp. 90-91, 11. 71-73. This translation is Halsall's).

\section{References}

Translated and Edited by Michael Allen, and Daniel Calderand. 1976, Sources and Analogues of Old English Poetry: The Major Latin Texts in Translation. Cambridge: D. S. Brewer.

Barnes, Michael. 2012. Runes: A Handbook. Woodbridge: Boydell.

Birkett, Tom. 2014a. Runes and Revelatio: Cynewulf's Signatures Reconsidered. The Review of English Studies 65: 771-89. [CrossRef]

Birkett, Tom. 2014b. Unlocking Runes? Reading Anglo-Saxon Runic Abbreviations in Their Immediate Literary Context. Futhark: International Journal of Runic Studies 5: 91-114.

Birkett, Tom. 2017a. Reading the Runes in Old English and Old Norse Poetry. New York and Abingdon: Routledge. [CrossRef]

Birkett, Tom. 2017b. Stitched Up? Cynewulf, Authorial Attribution and Textual Stasis in Anglo-Saxon England. In Stasis in the Medieval West? Questioning Change and Continuity. Edited by Michael D. J. Bintley, Martin Locker, Victoria Symons and Mary Wellesley. London: Palgrave, pp. 107-25. [CrossRef]

Translated and Edited by Robertand Bjork. 2013, The Old English Poems of Cynewulf. Cambridge and London: Harvard University Press.

Boren, James. 2001. Form and Meaning in Cynewulf's Fates of the Apostles. In The Cynewulf Reader. Edited by Robert Bjork. New York and London: Routledge, pp. 57-65. First published 1969. [CrossRef]

Brown, Michelle B. 2011. Writing in the Insular World. In The Cambridge History of the Book in Britain: Volume I. c. 400-1100. Edited by Richard Gameson. Cambridge: Cambridge University Press, pp. 121-66. [CrossRef]

Bunčić, Daniel, Sandra L. Lippert, and Achim Rabus, eds. 2016. Biscriptality: A Sociolinguistic Typology. Heidelberg: Universitätsverlag Winter.

Calder, Daniel. 1975. The Fates of the Apostles, The Latin Martyrologies and the Litany of the Saints. Medium Aevum 44: 219-24. [CrossRef]

Calder, Daniel. 1981. Cynewulf. Boston: Twayne Publishers.

Christie, Edward. 2003. The Image of the Letter: From the Anglo-Saxons to the Electronic Beowulf. Culture, Theory and Critique 44: 129-50. [CrossRef]

Derolez, René. 1954. Runica Manuscripta: The English Tradition. Bruges: De Tempel.

Derolez, René. 1990. Runic Literacy Among the Anglo-Saxons. In Britain 400-600: Language and History. Edited by Alfred Bammesberger and Alfred Wollmann. Heidelberg: C. Winter, pp. 397-436.

Derolez, René. 1991. Runica Manuscripta Revisited. In Old English Runes and their Continental Background. Edited by Alfred Bammesberger. Heidelberg: C. Winter, pp. 85-106.

DiNapoli, Robert. 2005. Odd Characters: Runes in Old English Poetry. In Verbal Encounters: Anglo-Saxon and Old Norse Studies for Roberta Frank. Edited by Antonina Harbus and Russell Poole. Toronto, Buffalo and London: University of Toronto Press, pp. 145-61. [CrossRef]

Elliott, Ralph. 1953a. Cynewulf's Runes in Christ II and Elene. English Studies 34: 49-57. [CrossRef]

Elliott, Ralph. 1953b. Cynewulf's Runes in Juliana and Fates of the Apostles. English Studies 34: 193-204. [CrossRef]

Elliott, Ralph. 1991. Coming Back to Cynewulf. In Old English Runes and their Continental Background. Edited by Alfred Bammesberger. Heidelberg: C. Winter, pp. 231-47.

Frese, Dolores. 1975. The Art of Cynewulf's Runic Signatures. In Anglo-Saxon Poetry: Essays in Appreciation. Edited by Lewis Nicholson and Dolores Frese. Notre Dame: University of Notre Dame Press, pp. 312-34.

Fulk, Robert. 2001. Cynewulf: Canon, Dialect, and Date. In The Cynewulf Reader. Edited by Robert Bjork. New York and London: Routledge, pp. 3-21. [CrossRef]

Genette, Gérard. 1997. Paratexts: Thresholds of Interpretation. Translated by Jane E. Lewin. Cambridge: Cambridge University Press. [CrossRef]

Gleason, Raymond. 1992. The Riddle of the Runes: The Runic Passage in Cynewulf's Fates of the Apostles. Essays in Medieval Studies 9: 19-32.

Halsall, Maureen, ed. 1981. The Old English Rune Poem: A Critical Edition. Toronto, Buffalo and London: University of Toronto Press. [CrossRef]

Hieatt, Constance. 2001. The Fates of the Apostles: Imagery, Structure, and Meaning. In The Cynewulf Reader. Edited by Robert Bjork. New York and London: Routledge, pp. 66-77. First published 1974. [CrossRef]

Krapp, George, ed. 1906. Andreas and The Fates of the Apostles: Two Anglo-Saxon Narrative Poems. Boston and London: Ginn and Company. McCulloh, John. 2000. Did Cynewulf Use a Martyrology? Reconsidering the Sources of The Fates of the Apostles. Anglo-Saxon England 29: 67-83. [CrossRef] 
McKee, Helen. 2014. The Wiley Blackwell Encyclopedia of Anglo-Saxon England. Edited by Michael Lapidge, John Blair, Simon Keynes and Donald Scragg. Chichester: Blackwell Publishing, pp. 423-24. [CrossRef]

Napier, Arthur. 1889. Collation der altenglischen Gedichte im Vercellibuch. Zeitschrift für Deutsches Altertum und Deutsches Literatur 33: 66-73.

Niles, John. 2003. The Trick of the Runes in The Husband's Message. Anglo-Saxon England 32: 189-223. [CrossRef]

Niles, John. 2006. Old English Enigmatic Poems and the Play of the Texts. Turnhout: Brepols. [CrossRef]

Orchard, Andy. 2003. Both Style and Substance: The Case for Cynewulf. In Anglo-Saxon Styles. Edited by Catherine Karkov and George Brown. Albany: State University of New York Press, pp. 271-305.

Orton, Peter. 2014. Writing in a Speaking World: The Pragmatics of Literacy in Anglo-Saxon Inscriptions and Old English Poetry. Tempe: Arizona Center for Medieval and Renaissance Studies Press.

Page, Raymond. 1999. An Introduction to English Runes, 2nd ed. Woodbridge: Boydell Press.

Parsons, David. 1999. Recasting the Runes: The Reform of the Anglo-Saxon Futhorc. Uppsala: Institutionen för Nordiska språk, Uppsala Universitet.

Puskar, Jason. 2011. Hwa pas fitte fegde? Questioning Cynewulf's Claim to Authorship. English Studies 92: 1-19. [CrossRef]

Schaar, Claes. 1967. Critical Studies in the Cynewulf Group. Lund: C.W.K. Gleerup.

Senra Silva, Inmaculada. 2010. The Names of the $u$-Rune. Futhark: International Journal of Runic Studies 1: 109-22. [CrossRef]

Sisam, Kenneth. 1953. Studies in the History of Old English Literature. Oxford: Clarendon Press.

Symons, Victoria. 2016. Runes and Roman Letters in Anglo-Saxon Manuscripts. Berlin and Boston: De Gruyter. [CrossRef]

Turco, Roberto Rosselli, ed. 2016. The Digital Vercelli Book, 2nd digital ed. Available online: http://vbd.humnet.unipi.it/beta2/index. html (accessed on 31 October 2021). 